\title{
A THORACALIS GERINC PROCESSUS TRANSVERSUSAINAK GEOMETRIAI VIZSGÁLATA
}

\author{
Csernátony Zoltán ${ }^{1}$, Hunya Zsolt ${ }^{1}$, Sikula Judit ${ }^{2}$, Kollár József ${ }^{2}$, \\ Molnár Szabolcs ${ }^{3}$ \\ ${ }^{1}$ Debreceni Egyetem Orvos- és Egészségtudományi Centrum, Ortopédiai Klinika \\ 2 Debreceni Egyetem Orvos- és Egészségtudományi Centrum, Radiológiai Klinika \\ ${ }^{3}$ Budai Irgalmasrendi Kórház, Ortopédiai Osztály \\ csz@med.unideb.hu
}

\begin{abstract}
Absztrakt
Munkacsoportunk évek óta foglalkozik a thoracalis gerinc biomechanikájával, kiemelt figyelmet szentelve a fiziológiás gerinc és a scolioticus deformitások sajátosságainak. A mútéti kezelést igénylô gerincdeformitások korrekciója során használt implantátum-rendszerek kiegészítőjeként szükség lehet olyan eszköz használatára, amely a thoracalis gerincszakasz csigolyáin, a processus transversusok bázisán támaszkodik. Összeállítottunk egy olyan kísérletsorozatot, amely során a végsố célunk az implantátumok tervezéséhez szükséges anatómiai és mechanikai információk gyűjtése, valamint a beültetésre kerülő eszközök megbízhatóságának radiológiai vizsgálómódszerekkel történő preoperatív meghatározása volt. Vizsgálatainkhoz cadaverekből távolítottunk el háti gerincszakaszokat. Az elsô fázisban a háti csigolyák processus transversusainak anatómiai méreteit vizsgáltuk radiológiai módszerek segítségével. A második részben a computertomographiás (továbbiakban CT) felvételekrôl meghatározható csontsûrûséget mértük. A vizsgálatok utolsó részeként pedig a processus transversusok (bio)mechanikai ellenálló képességét és annak preoperatív, CT-felvételekkel való megítélhetőségét vizsgáltuk. Jelen közleményünkben az elsô fázis eredményeit, a thoracalis gerinc processus transversusainak radiológiai vizsgálómódszerekkel meghatározott geometriai paramétereit ismertetjük.
\end{abstract}

Kulcsszavak: thoracalis gerinc; biomechanika; scoliosis; implantátum; processus transversus Keywords: thoracal spine; biomechanics; scoliosis; implants; processus transversus

\section{Bevezetés}

A scoliosis sebészi kezelésében forradalmi változást jelentett a Cotrel és Dubousset által bevezetett derotációs koncepció, amelyet a róluk elnevezett (továbbiakban CD) implantátum használata során alkalmaztak ${ }^{1}$. Ezt az újítást felhasználva számtalan beültetendô változat jelent meg - fejlesztve ezzel a sebészi technikát és az implantátumgyártást. A mûtéti eredmények értékelésekor szignifikáns számú reziduális patológiás rotációt lehetett dokumentálni, amely annak a következménye, hogy a frontális és szagittális görbület reduk- ciója során a relatív rotáció gyakran növeke$\operatorname{dett}^{2,3,4,5}$. Munkacsoportunk vezetôje a CDrendszerek kiegészítőjeként fejlesztette ki a „CAB” horgot ${ }^{6,7,8}$. A kiegészítő implantátum használata közben, a horgot a thoracalis gerinc csigolyáinak processus transversusaira kell felhelyezni. A beültetendő eszköz biomechanikai tesztelése és az első klinikai tapasztalatok ${ }^{7}$ után igény merült fel különbözô méretû és geometriájú implantátumok készítésére. Munkánk során célul tûztük ki a háti gerinc processus tranversus anatómiai paramétereinek könnyen hozzáférhetố radiológiai vizsgálómódszer alapján való meghatározását. 
Biomechanica Hungarica I. évfolyam, 1. szám

A gerinc morfológiájának radiológiai vizsgálatára számos példát találunk az irodalomban $^{9,10,11,12}$. A gerincszakaszokról készített, hagyományos axiális CT-scaneken a transzverzális síkban, az ezekből előállított rekonstrukciós felvételeken pedig a szagittális síkban vizsgáltuk a processus transversusok méreteit, és megállapítottuk azok szórását.

\section{Anyag és módszer}

Kísérletsorozatunk során összesen 10 db cadaverekből eltávolított háti gerincszakasz processus transversusainak anatómiai paramétereit vizsgáltuk. A preparátumok a teljes thoracalis gerincszakaszból (Th1-12, esetenként a kísérletben fel nem használt C7, illetve L1 csigolyákból), valamint a hozzá tartozó bordacsonkokból álltak (1. ábra). Az idevágó irodalom áttekintése során arra a következtetésre jutottunk, hogy mérési eredményeinket nem befolyásolja a tény, hogy lágyrészektôl megfosztott gerincszakaszokkal dolgozunk ${ }^{13}$. Az eltávolítás után a preparátumok egy részét - a méréssorozat egy további fázisának menetét megkönnyítendố - a borda-csonkoktól megfosztottuk, és csigolyapárokra szedtük szét: Th1-2, Th3-4, Th5-6, Th7-8, Th9-10, Th1112 (2. ábra). A cadaverek átlagéletkora 68 év (25-91) volt, nő:férfi arány 6:4. A minták eltávolítása és preparálása a Debreceni Egye-

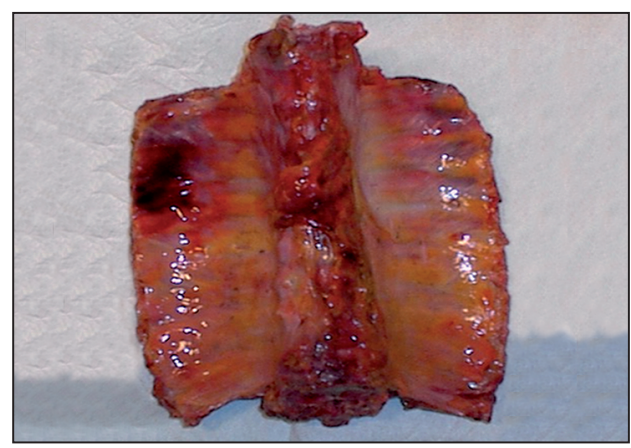

1. ábra. Cadaverbốl eltávolított thoracalis gerincszakasz tem Pathológiai Intézetében és Biomechanikai Laboratóriumában, a Debreceni Egyetem Orvos- és Egészségtudományi Centrum Etikai Bizottságának engedélyével (DOTE RKEB/ IKEB - Prot. No. 2099/2003) történtek.

A preparátumok eltávolítása után, azokról computertomographiás rétegfelvételeket készítettünk (7 db gerincszakaszt a fent leírt módon csigolyapáronként, 3 db-ot pedig egészben vizualizáltunk). A CT-felvételek elkészítése és az azokon végzett mérések a Debreceni Egyetem Radiológiai Klinikáján történtek. A vizsgálat kivitelezéséhez GE Dual CT-készüléket használtunk. A leképezés során $3 \mathrm{~mm}$ rétegvastagságú felvételeket készítettünk, amelyek a csigolyák transzverzális síkú metszeteit reprezentálják. A leképezéskor a csigolyákat a vizsgálóasztalra tett ovális fejtartóban stabilizáltuk (3. ábra). A 7 db szétbontott gerincszakasz esetében minden csigolyapárt külön-külön helyeztünk a vizsgálóasztalra, míg a 3 egészben lévố gerincszakasz esetében a teljes mintát (a teljes thoracalis gerinc mindegyik bordacsonkkal) vizsgáltuk, és - mint az elôzőekben - csigolyapáronként készítettünk felvételeket. Ekkor a preparátumot, annak görbülete miatt (fiziológiás thoracalis kyphosis) minden „scan” után újra kellett pozicionálni, hogy az adott felvételen a meghatározandó csigolya pontos horizontális síkú metszete legyen látható.

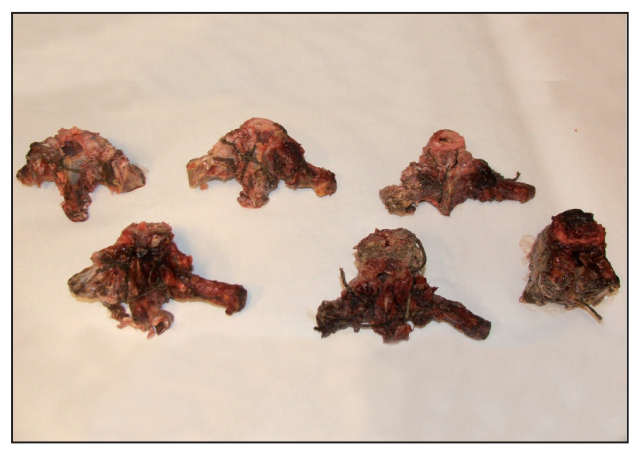

2. ábra. A cadaverekból eltávolított gerincszakaszok csigolyapárokra bontás után 


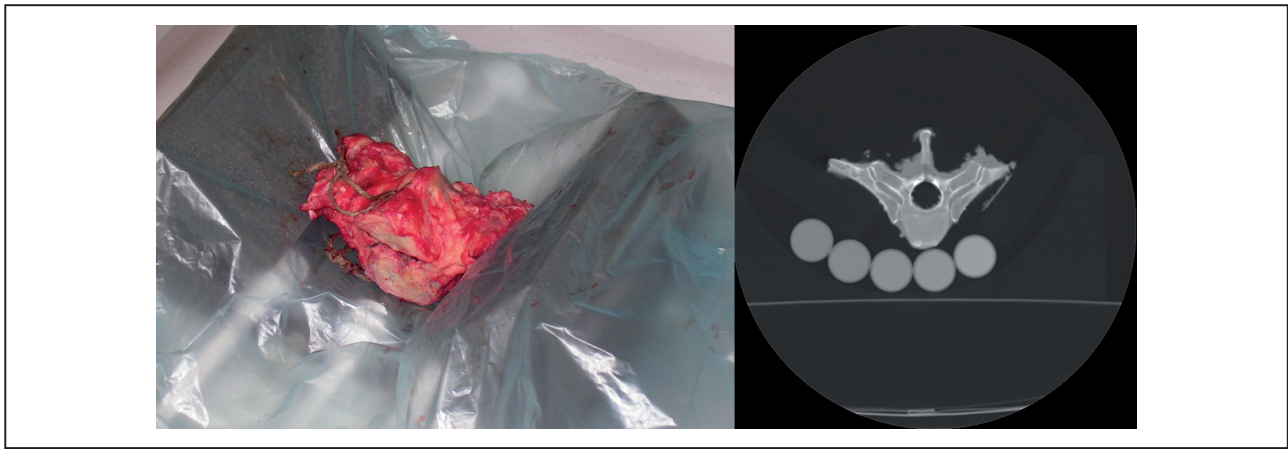

3. ábra. A preparátumok CT-vel való leképezése és az elkészült axiális scan

A következő lépésben az axiális felvételeken egy, a Radiológiai Klinikán a diagnosztikában is gyakran alkalmazott szoftver segítségével meghatároztuk a vizsgált csigolyák processus transversusainak horizontális átmérôjiét (4. ábra). Az elkészült felvételek alapján, ugyanezen szoftvert használva szagittális síkú rekonstrukciós képeket készítettünk, és ezeken megmértük a csigolyanyúlványok vertikális átmérőjét is (5. ábra). A mérések során az átmérőket előre meghatározott területen, a processus transversusok tövénél - ahol a korábbiakban említett implantátum rögzül vizsgáltuk. Az adatokat táblázatba foglaltuk, grafikonon ábrázoltuk és statisztikai elemzéseket végeztünk.

\section{Eredmények}

Összesen 120 thoracalis csigolya (10 thoracalis gerincen Th1-12 között) 240 processus transversusának vizsgálatára volt lehetôségünk. Az eltávolítás során történő sérülés, illetve a rekonstrukció hibahatára miatt 443 értékelhetô mérési eredményt (218 vertikális és 225 horizontális átmérô) kaptunk. A vertikális átmérôk 7,4 és 18 mm között változtak. Csigolyánkénti átlagukat az 1. grafikon szemlélteti. A Th1 és 11 közötti csigolyáknál 18, 19 vagy 20 eredmény állt rendelkezésünkre, a 12-es háti csigolyánál csak 7. Ennek oka a Th-12 rövid, vastag nyúlványainak sérülékeny- sége. Látható, hogy ezen átlagok nagy része 13 és 14 mm között mozog (12,9-14,2 mm-ig). A vertikális átmérők eloszlását a 2. grafikon ábrázolja. A leggyakrabban előforduló átmérôk: 12,5 mm-tôl 15,5 mm-ig a teljes halmaz 66\%-át teszik ki. Amennyiben a legkisebb vertikális átmérôtől vizsgáljuk, 15,5 mm-es nagyságig az összes átmérő $88,5 \%$-a található ebben a csoportban.

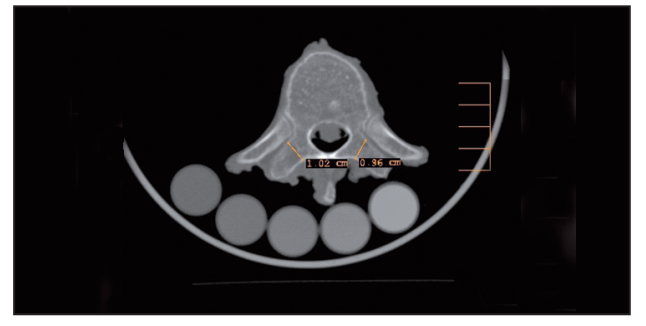

4. ábra. A processus transversusok horizontális átmérôjének meghatározása

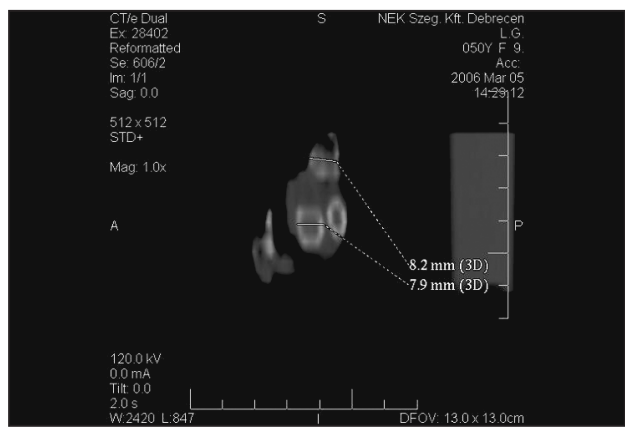

5. ábra. Szagittális rekonstrukciós CT-kép és a csigolyanyúlványok vertikális átmérőjének mérése 
Biomechanica Hungarica I. évfolyam, 1. szám

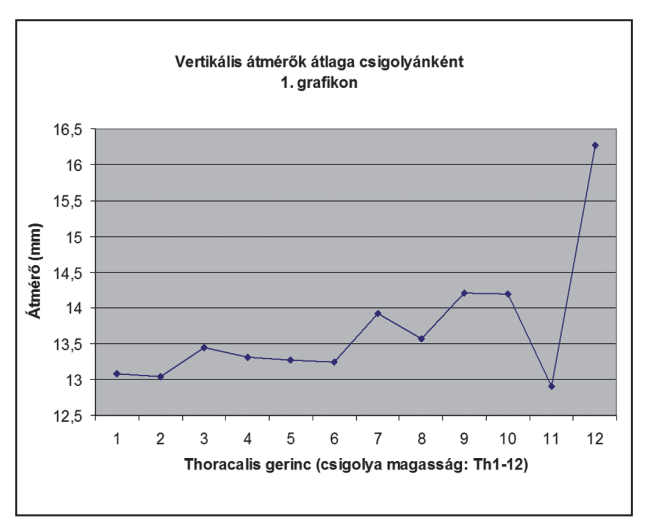

1. grafikon. Vertikális átmérők átlaga csigolyánként

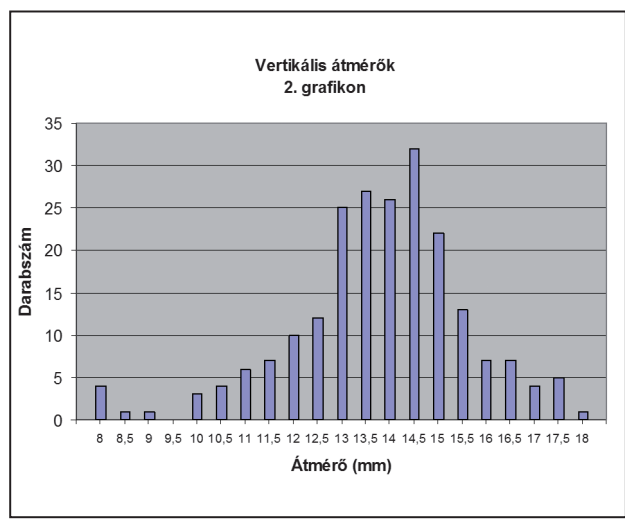

2. grafikon. A csigolyák számának eloszlása a vertikális átmérôjük alapján

A horizontális átmérôk 6,7 és 12,8 mm között változtak. Csigolyánkénti átlagukat a 3. grafikon szemlélteti. A Th1 és 11 közötti csigolyáknál 18, 19 vagy 20 eredmény állt rendelkezésünkre, a 12-es háti csigolyánál csak 11. Ennek oka szintén az alsó thoracalis csigolyanyúlványok sérülékenysége. Látható, hogy ezen átlagok 8,5 és $10 \mathrm{~mm}$ között mozognak (8,55-10,115 mm-ig). A horizontális átmérôk eloszlását a 4. grafikon ábrázolja. A leggyakrabban előforduló átmérôk: 8,5 mm-tôl 11,5 mmig a teljes halmaz $82 \%$-át teszik ki. Amennyiben a legkisebb horizontális átmérôtôl vizsgáljuk, 11,5 mm-es nagyságig az összes átmérô 96\%-a található ebben a csoportban.

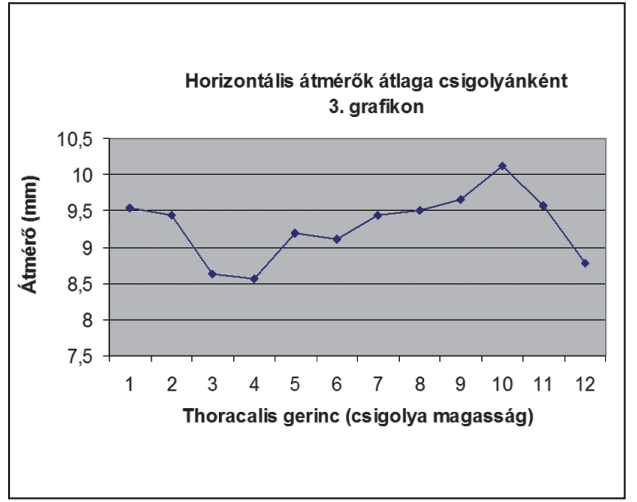

3. grafikon. Horizontális átmérôk átlaga csigolyánként

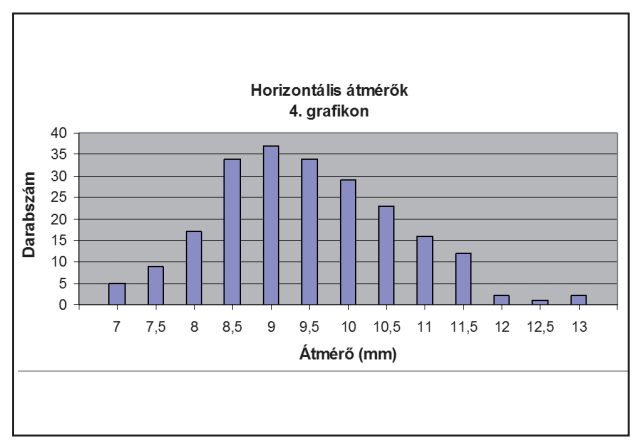

4. grafikon. A csigolyák számának eloszlása a horizontális átmérôjük alapján

\section{Összefoglalás}

A thoracalis gerinc biomechanikája rendkívül összetett és nehezen modellezhetô. A mûtéti kezelést igénylő gerincdeformitások korrekciója kiemelt jelentőséggel bír a test harmóniájának, egyensúlyának, esztétikájának helyreállítása, valamint a mútéttel kapcsolatos nehézségek (nagy mennyiségú implantátum, kiterjedt feltárás) miatt. Az alkalmazott implantátumrendszerek az elmúlt évtizedekben dinamikus fejlődésen mentek keresztül, ugyanakkor a thoraco-lumbalis régió összetett biomechanikai múködése miatt számos buktatóval rendelkeznek ${ }^{14}$. Ezen implantátumok kiegészítôjeként szükséges lehet olyan 
eszköz használata, amely a thoracalis gerincszakasz csigolyáin, a processus transversusok bázisán támaszkodik. Összeállítottunk egy három fázisból álló kísérletsorozatot, amely során könnyen hozzáférhetô radiológiai módszer segítségével meghatároztuk a háti csigolyák processus transversusainak átlagos anatómiai méreteit (1. fázis), majd a CT-felvételekről meghatározható csontsûrû́séget mértük (2. fázis) és a vizsgálatok utolsó részeként a processus transversusok biomechanikai ellenállóképességét és annak preoperatív, computertomographiás felvételekkel való megítélhetőségét vizsgáltuk (3. fázis). A mérések végsố célja az implantátumok tervezéséhez szükséges anatómiai és mechanikai információk gyújtése, valamint a beültetésre kerülő eszközök megbízhatóságának radiológiai vizsgálómódszerekkel történô preoperatív meghatározása volt. Jelen közleményünkben az elsô fázis - a thoracalis gerinc processus transversusainak CT-vel történố geometriai vizsgálatáról számoltunk be. A radiológiai mérési eredményekből azt a következtetést vonhatjuk le, hogy a processus transversusok verti- kális és horizontális átmérối egy jól meghatározott tartományba esnek. A legegyszerúbb esetben vertikálisan 15,5 mm-es - tehát minden, tôle kisebb átmérốre jó -, horizontálisan pedig 11,5 mm-es „horog” a betegek 88,5, illetve 96\%-ban alkalmazható. Amennyiben a későbbiekben ennél nagyobb pontosságot várunk el, a méretezésnél szóba jövő maximális implantátumszám a következő módon alakulhat: a vertikális értékek alapján 12,5 és 15,5 mm közötti tartományt nézve, ahol az esetek 66\%-át találjuk meg - a legprecízebb méretkülönbséget $(1 \mathrm{~mm})$ választva is legfeljebb 3 implantátum méretre van/lehet szükség. Ugyanezt a logikai menetet követve a horizontális átméróknél 8,5 és 11,5 mm között ahol az esetek 82\%-a található - szintén 3 mérettartományt kell a gyártásnál megkülönböztetni. Vagyis a legaprólékosabb tervezést figyelembe véve is maximum $3 \times 3=9$ implantátum sorozattal kell rendelkeznünk. Ezen eredmények felhasználásával lehetőség van az eszközök sorozatgyártására, valamint mútét előtt készített CT-felvételek alapján a megfelelő implantátum kiválasztására.

Köszönetnyilvánítás

A szerzốk ezúton szeretnék kifejezni köszönetüket a Debreceni Egyetem Radiológiai Klinika munkatársainak a CT-felvételek készítésében végzett segítségükért, valamint a Pathológiai Intézet munkatársainak a cadaver tanulmányokban nyújtott részvételükért.

\section{IRODALOM}

1. Cotrel Y, Dubousset J. Nouvelle technique d'ostéosynthčse rachidienne segmentaire par voie postérieure. Rev Chir Orthop 1984; 70:489-94.

2. Dubousset J. Assessment of the rotational deformity. In: Canadell J, Forriol F, Cara JA, editors. Idiopathic scoliosis update. Basic research and clinical concepts. Pamplona: University of Navarra, Medical School Pamplona; 1991. p. 311-6.
3. Krismer M, Bauer R, Sterzinger W. Scoliosis correction by Cotrel-Dubousset instrumentation. The effect of derotation and three dimensional correction. Spine 1992;17 Suppl 8:263-9.

4. Csernátony Z, Gáspár L, Benkő K, Fekete Zs, Soós $P$, Nyulasi $T$, et al. Experimental studies for the surgical correction and fixation of dorsal spine deformities. Acta Chir Hung 1997; 36:51-3. 
Biomechanica Hungarica I. évfolyam, 1. szám

5. Csernátony Z, Szepesi K, Gáspár L, Kiss L. Contradictions of derotation in scoliosis surgery using the CD principle. Medical Hypotheses 2002;58(6):498-502.

6. Csernátony Z. Egy új típusú háti implatátum, a „CAB” kifejlesztése a scoliosis hátsó behatolásból végzett mútéti kezeléséhez [PhD thesis]. Debrecen: Debreceni Orvostudományi Egyetem; 1999.

7. Csernátony Z, Fekete Zs, Soós P, Nyulasi T, Gáspár L. A háti szakasz scoliosisának módosított instrumentálása. Elsổ klinikai tapasztalatok a CAB horgok alkalmazásával. Magyar Traumat Ortop 1999;42:42-6.

8. Csernátony Z, Goodship A, Szepesi K, Jónás Z, Gáspár L, Benkó K, et al. A complementary thoracic implant for the surgical correction of the scoliotic curve. A preliminary report. Eur J Orthop Traumatol 2001;11:85-9.

9. Landry C, De Guise JA, Dansereau J, Labelle H, Skalli $W$, Zeller $R$, et al. Computer graphic analysis of the three-dimensional deformities of scoliotic vertebrae. Ann Chir 1997;51(8):868-74.
10. Panjabi MM, Takata K, Goel V, Federico D, Oxland T, Duranceau J, Krag M. Thoracic human vertebrae. Quantitative three-dimesional anatomy. Spine 1991;16(8):888-901.

11. Kothe R, O'Holleran JD, Liu W, Panjabi MM. Internal architecture of the thoracic pedicle. An anatomic study. Spine 1996;21(3):264-70.

12. Panjabi MM, Shin EK, Chen NC, Wang JL. Internal morphology of human cervical pedicles. Spine 2000;25(10):1197-205.

13. Lee S, Harris KG, Nassif J, Goel VK, Clark CR. In vivo kinematics of the cervical spine. Part I: Development of a roentgen stereophotogrammetric technique using metallic markers and assessment of its accuracy. J Spinal Disord 1993;6(6):522-34.

14. Molnár Sz, Manó S, Kiss L, Csernátony Z. Ex vivo and in vitro determination of the axial rotational axis of the human thoracic spine. Spine 2006;31(26):E984-E991

A szerzók kijelentik, hogy a kísérletsorozat a hatályos magyar jogszabályoknak megfelelöen, a Debreceni Egyetem Orvos- és Egészségtudományi Centrum Etikai Bizottságának engedélyével (DOTE RKEB/IKEB - Prot. No. 2099/2003) történt.

\section{A kisérletek megvalósitása során a szerzók semmiféle anyagi támogatásban nem részesültek.}

Csernátony Zoltán

Debreceni Egyetem Orvos- és Egészségtudományi Centrum, Ortopédiai Klinika 4012 Debrecen, Nagyerdei krt. 98.

Tel.: (+36) 52 415-494 